\title{
Implementasi Strategi Writing to Learn untuk Meningkatkan Kemampuan Kognitif dan Keterampilan Berpikir Kritis Siswa SMA pada Materi Hukum Newton
}

\author{
Hilda Nurul Melida ${ }^{\text {a)}}$, Parlindungan Sinaga ${ }^{\text {b) }}$, Selly Feranie ${ }^{\text {c) }}$ \\ Departemen Pendidikan Fisika, Fakultas Pendidikan Matematika dan Ilmu Pengetahuan Alam, \\ Universitas Pendidikan Indonesia, Jl. Dr. Setiabudhi No. 229, Bandung, 40154

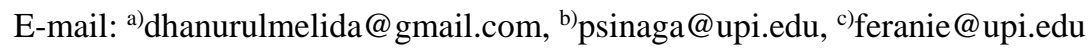

\begin{abstract}
The result of former study showed that students' cognitive ability and critical thinking skills were still low. The 'writing to learn' strategy is predicted to be able to enhance students' cognitive ability and critical thinking skills. The aims of this research are (1) investigate the comparison of cognitive ability and critical thinking skills enhancement between the classes that apply the use of 'writing to learn' strategy and the classes that administer conventional learning, (2) examine the effectiveness of 'writing to learn' strategy in improving cognitive ability and critical thinking skills, and (3) examine the relationship between the quality of writing and cognitive ability and critical thinking skills. This research used nonequivalent control group design in high school one of Bandung. The result showed the implementation of 'writing to learn' strategy increased students' cognitive ability and critical thinking skills of newtons' laws of motion in experiment class, i.e. with each value of $n$-gain was 0.58 and 0.67 that the increase was higher than the control class, i.e. with each value of n-gain was 0.36 and 0.50. 'Writing to learn' strategy gave an impact towards the enhancement of students' cognitive ability and critical thinking skills with each value of the effect size was 0.80 and 1.1. The quality of writing gave enough contribution in improving cognitive ability and critical thinking skills with each coefficient of correlation 0.24 and 0.63 .
\end{abstract}

Keywords: Writing to learn strategy, cognitive ability, critical thinking skills.

\begin{abstract}
Abstrak
Hasil studi pendahuluan memperlihatkan bahwa siswa memiliki kemampuan kognitif dan keterampilan berpikir kritis yang masih rendah. Strategi writing to learn diprediksi dapat meningkatkan kemampuan dan keterampilan berpikir kritis siswa. Penelitian ini bertujuan untuk (1) mengetahui perbandingan peningkatan kemampuan kognitif dan keterampilan berpikir kritis antara kelas yang menggunakan strategi writing to learn dengan kelas yang melaksanakan pembelajaran konvensional, (2) mengetahui keefektifan strategi writing to learn dalam meningkatkan kemampuan kognitif dan keterampilan berpikir kritis, serta (3) mendapat gambaran mengenai hubungan antara kualitas menulis dengan kemampuan kognitif dan keterampilan berpikir kritis. Penelitian ini menggunakan desain nonequivalent control group design di salah satu SMA Negeri di kota Bandung. Hasil penelitian menunjukkan adanya pengaruh dari implementasi strategi writing to learn dalam meningkatan kemampuan kognitif dan keterampilan berpikir kritis pada materi hukum Newton di kelas eksperimen, yaitu dengan masing-masing nilai n-gain sebesar 0,58 dan 0,67 yang lebih besar peningkatannya dibandingkan dengan kelas kontrol, yaitu dengan masing-masing nilai n-gain sebesar 0,36 dan
\end{abstract}


0,50. Strategi writing to learn berdampak pada peningkatkan kemampuan kognitif dan keterampilan berpikir kritis siswa dengan masing-masing nilai effect size yaitu 0,80 dan 1,1. Kualitas menulis cukup berkontribusi dalam meningkatkan kemampuan kognitif dan keterampilan berpikir kritis dengan masing-masing koefisien korelasi 0,63 dan 0,24.

Kata-kata kunci: Strategi writing to learn, kemampuan kognitif, keterampilan berpikir kritis.

\section{PENDAHULUAN}

Berdasarkan standar isi Kurikulum Tingkat Satuan Pendidikan (Depdiknas, 2006, p. 443) dan kurikulum 2013 (Depdikbud, 2013, p. 900), tujuan pembelajaran Fisika SMA salah satunya yaitu agar peserta didik memiliki kemampuan kognitif dan keterampilan berpikir kritis. Dari pernyataan tersebut, maka kemampuan kognitif dan keterampilan berpikir kritis merupakan hal yang sangat penting. Oleh karena itu, pada pembelajaran Fisika di sekolah, diharapkan pendidik mampu memfasilitasi untuk meningkatkan kemampuan kognitif dan keterampilan berpikir kritis peserta didik.

Ennis, R. H. (1985) menyatakan bahwa berpikir kritis adalah berpikir reflektif dan beralasan yang berfokus pada pengambilan keputusan tentang apa yang harus dipercaya atau dilakukan. Dalam keterampilan berpikir kritis, siswa dituntut untuk dapat menganalisis argumen, membuat kesimpulan menggunakan penalaran induktif atau deduktif, menilai atau mengevaluasi, dan membuat keputusan atau memecahkan masalah.

Pengetahuan teoritis siswa dapat mempengaruhi pada penilaian dan pengambilan keputusan mereka, karena, untuk memecahkan suatu masalah, siswa harus mengetahui dan memahami mengenai permasalahannya terlebih dahulu, sehingga siswa mampu memecahkan masalah yang dihadapinya. Maka dari itu berpikir kritis melibatkan kemampuan kognitif. Menurut K-Chao Yu peh (dalam Susana, E. S. H., dan Sriyansyah, 2015), kemampuan kognitif berkaitan erat dengan keterampilan berpikir kritis. Oleh karena itu, untuk mengembangkan keterampilan berpikir kritis, tentu juga harus bersamaan dengan melatihkan kemampuan kognitif siswa.

Terkait hal tersebut, setelah dilakukan studi lapangan untuk materi hukum Newton yaitu pemberian tes kepada 30 sampel di salah satu SMA yang berada di kota Bandung, didapatkanlah data bahwa 97\% siswa berada di bawah KKM (dengan KKM yang ditetapkan yaitu 75). Dari data tersebut dapat diketahui bahwa siswa memiliki kemampuan kognitif dan keterampilan berpikir kritis yang masih rendah. Salah satu faktor yang dapat mengakibatkan rendahnya kemampuan kognitif dan keterampilan berpikir kritis siswa yaitu kurangnya minat siswa untuk belajar fisika karena beberapa alasan. Hasil angket yang telah diisi oleh siswa mengenai pembelajaran fisika di sekolah menunjukkan bahwa $100 \%$ siswa tidak menyukai fisika, salah satunya alasannya yaitu terlalu banyak rumus. Selain itu, siswa mengungkapkan bahwa metode yang digunakan guru selama pembelajaran yaitu ceramah. Hal itu menyebabkan siswa kurang dilatih berpikir kritis dan kognitifnya. Hasil penelitian sebelumnya (Susana, E. S. H., dan Sriyansah, 2015) menunjukkan bahwa secara umum kemampuan kognitif dan keterampilan berpikir kritis siswa masih cukup rendah, yaitu dilihat dari hasil pembelajaran yang rata-rata berada di bawah KKM yang telah ditentukan.

Menurut Galbraith (dalam Chen, Y. C et al, 2013), menulis dapat dipandang sebagai sebuah alat yang dapat membangun pengetahuan. Dengan menulis, pemahaman siswa yang belum tertata akan lebih terkoordinasi secara utuh. Manfaat menulis juga disebutkan oleh Santa, C. M dan Havens, L. T (1991), yaitu sebagai berikut:

1. Menulis menghubungkan pengetahuan sebelumnya

2. Menulis membantu siswa dalam metakognitif.

3. Menulis mendorong siswa untuk berperan aktif dalam pembelajaran

4. Menulis membangun keterampilan mengorganisasi informasi

Dengan mengetahui pentingnya menulis, maka strategi pembelajaran yang dapat digunakan yaitu strategi writing to learn. Menurut Michigan Science Teachers Association (1987), strategi writing to learn adalah strategi yang digunakan guru pada seluruh dan/atau diakhir pembelajaran untuk mengikutsertakan siswa-siswa dalam mengembangkan ide dan konsep yang besar. Strategi ini dapat membantu dalam perkembangan berpikir kritis, analisis, dan aplikasi sehingga dapat membantu 
siswa dalam berpikir konsep dan ide-ide. Melalui kegiatan menulis ini siswa menjadi pembaca dan pemikir yang lebih baik.

Strategi writing to learn ini dapat dilakukan dengan menulis jurnal. Waters, P. M (2014) menjelaskan bahwa dengan menulis jurnal memungkinkan siswa untuk merangkum informasi yang baru diperoleh untuk refleksi lebih lanjut dan untuk menentukan hal-hal kejelasan, penjelasan lebih dalam, serta pengembangan. Menurut Michigan Science Teachers Association (1987), sebuah jurnal adalah catatan pembelajaran siswa yang dapat digunakan untuk refleksi dari hasil membaca atau kelas diskusi.

Hasil penelitian sebelumnya yang telah dilakukan (Chen, Y. C et al, 2013; Atasoy, S, 2013; Fellow, N. J, 1994), menunjukkan bahwa strategi writing to learn memberikan pengaruh positif dalam meningkatkan kemampuan kognitif. Selain itu, hasil penelitian yang telah dilakukan oleh Sinaga et al (2013) strategi writing to learn, learning to write mampu meningkatkan kemampuan kognitif dan keterampilan menulis siswa. Berdasarkan studi literatur masih jarang sekali yang melaporkan bagaimana pengaruh penerapan strategi writing to learn dalam meningkatkan keterampilan berpikir kritis.

Pada penelitian ini, selain untuk meningkatkan kemampuan kognitif, strategi writing to learn juga diimplementasikan untuk meningkatkan keterampilan berpikir kritis siswa. Maka dari itu, tujuan penelitian ini yaitu untuk mengetahui peningkatan kemampuan kognitif dan keterampilan berpikir kritis siswa antara kelas yang menggunakan strategi writing to learn dengan kelas yang melaksanakan pembelajaran konvensional; mengetahui keefektifan strategi writing to learn dalam meningkatkan kemampuan kognitif dan keterampilan berpikir kritis; serta mendapatkan gambaran mengenai hubungan antara kualitas menulis dengan peningkatan kemampuan kognitif dan keterampilan berpikir kritis.

\section{METODE PENELITIAN}

Metode penelitian yang digunakan yaitu metode quasi experimental dan desain eksperimental yang digunakan dalam penelitian ini yaitu nonequivalent control group design (Sugiyono, 2014). Kelas eksperimen merupakan kelas yang diberikan perlakuan (treatment) berupa strategi writing to learn, sedangkan kelas kontrol adalah kelas yang tidak diberikan treatment atau pembelajaran secara konvensional. Kedua kelas diberikan tes yang sama, yaitu sebelum dan setelah pembelajaran materi Hukum Newton.

Populasi dalam penelitian ini yaitu kelas X IPA tahun ajaran 2015/2016 di salah satu SMA Negeri yang berada di kota Bandung. Sampel yang diambil yaitu dua kelas X IPA, yaitu satu kelas sebagai kelas eksperimen dan satu kelas yang lain sebagai kelas kontrol dengan teknik purposive sampling.

Pada penelitian ini, aspek yang dinilai yaitu peningkatan kemampuan kognitif dan keterampilan berpikir kritis siswa yang dihitung dengan menggunakan $n$-gain, keefektifan strategi writing to learn dalam meningkatkan kemampuan kognitif dan keterampilan berpikir kritis yang dihitung dengan menggunakan effect size, serta hubungan kualitas menulis dengan peningkatan kemampuan kognitif dan keterampilan berpikir kritis yang dihitung dengan menggunakan korelasi linear.

Tes kemampuan kognitif siswa mengenai hukum Newton berupa soal pilihan ganda berdasarkan kategori dimensi proses kognitif taksonomi Bloom revisi yang telah dibatasi yaitu meliputi mengingat (C1), memahami (C2), mengaplikasikan (C3), dan menganalisis (C4). Sedangkan tes keterampilan berpikir kritis siswa mengenai hukum Newton berupa soal uraian berdasarkan aspek dan indikator yang telah dirumuskan oleh Ennis, R. H. (1985) dan telah membatasinya hanya dengan menggunakan 3 aspek dan indikator, yaitu memberikan penjelasan sederhana (menganalisis pertanyaan), membangun keterampilan dasar (mempertimbangkan sumber dapat dipercaya atau tidak), menyimpulkan (menginduksi dan mempertimbangkan hasil induksi). 


\section{HASIL DAN PEMBAHASAN}

\section{Peningkatan Kemampuan Kognitif dan Keterampilan Berpikir Kritis}

Peningkatan kemampuan kognitif dan keterampilan berpikir kritis siswa dapat dilihat dari hasil pretest dan posttest yang telah didapatkan yang kemudian dihitung dengan rata-rata skor gain yang dinormalisasi $\langle\mathrm{g}>$. Peningkatan kemampuan kognitif siswa dapat dilihat pada TABEL 1 di bawah.

TABEL 1. Peningkatan Kemampuan Kognitif Siswa Kelas Kontrol dan Eksperimen

\begin{tabular}{ccccc}
\hline \multirow{2}{*}{ Kelas } & \multicolumn{3}{c}{ Rata-Rata } & \multirow{2}{*}{ Kategori } \\
\cline { 2 - 4 } & Pretest & Postest & $\boldsymbol{g}$ & \\
\hline Kontrol & 38,43 & 60,39 & 0,36 & Sedang \\
\hline Eksperimen & 27,06 & 69,65 & 0,58 & Sedang \\
\hline
\end{tabular}

Untuk lebih jelas melihat perbedaan peningkatan kemampuan kognitif siswa dapat dilihat pada GAMBAR 1.

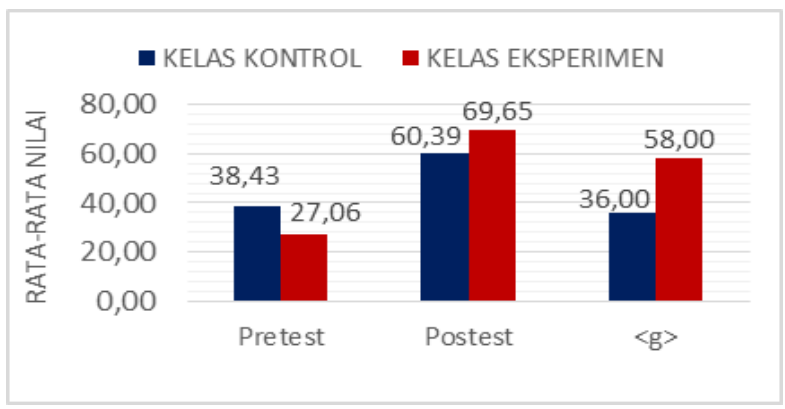

GAMBAR 1. Perbandingan Nilai Rata-Rata Pretest, Postest, dan $N$-gain Kemampuan Kognitif Kedua Kelas.

Berdasarkan TABEL 1 dan GAMBAR 1 di atas, diketahui bahwa nilai pretest kelas eksperimen lebih kecil daripada kelas kontrol. Namun, jika dilihat nilai postest masing-masing kelas, terlihat bahwa skor postest kelas eksperimen lebih besar daripada kelas kontrol. Dilihat dari hasil di atas, dapat disimpulkan bahwa kedua kelas mengalami peningkatan dalam hal kemampuan kognitifnya. Akan tetapi, besar peningkatan kemampuan kognitif kelas eksperimen dengan kelas kontrol berbeda, hal ini terlihat dari nilai $n$-gain masing-masing kelas, yaitu 0,58 untuk kelas eksperimen dan 0,38 untuk kelas kontrol. Dengan kata lain, peningkatan kemampuan kognitif kelas eksperimen lebih besar dibandingkan dengan kelas kontrol.

Setelah diketahui bahwa peningkatan kemampuan kognitif siswa pada kedua kelas berada pada kategori sedang, maka untuk mengetahui efek treatment terhadap kemampuan kognitif siswa digunakan Cohen's d effect size. Besarnya dampak strategi writing to learn terhadap peningkatan kognitif disajikan pada TABEL 2 berikut.

TABEL 2. Keefektifan Strategi Writing to Learn Terhadap Kemampuan Kognitif

\begin{tabular}{ccccccc}
\hline \multirow{2}{*}{ Kelas } & \multicolumn{2}{c}{ Rata-Rata } & \multicolumn{2}{c}{ STDev } & \multirow{2}{*}{ Sd $_{\text {pooled }}$} & \multirow{2}{*}{$\boldsymbol{d}$} \\
\cline { 2 - 5 } & Pretest & Posttest & Pretest & Posttest & & \\
\hline Eksperimen & 27,06 & 69,65 & 8,14 & 15,25 & \multirow{2}{*}{12,17} & \multirow{2}{*}{0,8} \\
\hline Kontrol & 38,43 & 60,39 & 9,86 & 9,39 & & \\
\hline
\end{tabular}

Berdasarkan TABEL 2, perhitungan effect size yang didapatkan yaitu sebesar 0,8 dan termasuk kriteria tinggi. Sehingga dapat disimpulkan bahwa strategi writing to learn memberikan dampak dalam meningkatkan kemampuan kognitif siswa.

Setelah mengetahui peningkatan kemampuan kognitif, maka peningkatan keterampilan berpikir kritis siswa dapat dilihat pada TABEL 3. 
TABEL 3. Peningkatan Keterampilan Berpikir Kritis Siswa Kelas Kontrol dan Eksperimen

\begin{tabular}{ccccc}
\hline \multirow{2}{*}{ Kelas } & \multicolumn{3}{c}{ Rata-Rata } & \multirow{2}{*}{ Kategori } \\
\cline { 2 - 4 } & Pretest & Postest & $\boldsymbol{g}$ & \\
\hline Kontrol & 9,33 & 54,67 & 0,50 & Sedang \\
\hline Eksperimen & 1,96 & 67,91 & 0,67 & Sedang \\
\hline
\end{tabular}

Untuk lebih jelasnya, peningkatan keterampilan berpikir kritis digambarkan pada GAMBAR 2 berikut.

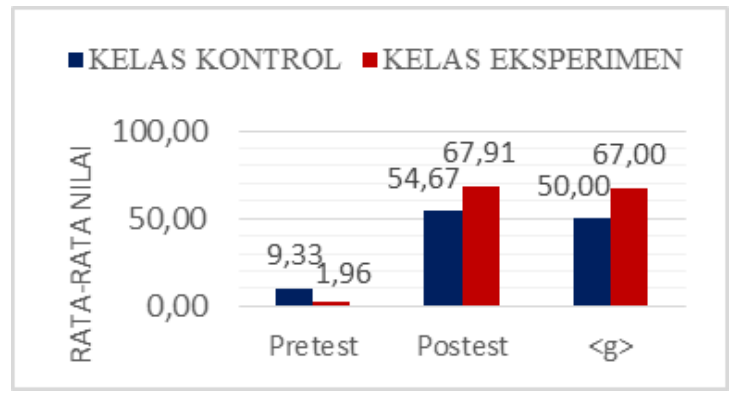

GAMBAR 2. Perbandingan Nilai Rata-Rata Pretest, Postest, dan $\mathrm{N}$-gain Keterampilan Berpikir Kritis Kedua Kelas.

Dari TABEL 3 dan GAMBAR 2, diketahui bahwa kedua kelas mengalami peningkatan keterampilan berpikir kritis. Besarnya peningkatan tersebut dapat dilihat dari nilai $n$-gain kedua kelas, yaitu 0,50 untuk kelas kontrol dan 0,67 untuk kelas eksperimen, dengan masing-masing kelas berada pada kategori sedang. Namun, besarnya peningkatan keterampilan berpikir kritis kelas eksperimen berbeda dengan kelas kontrol. Peningkatan keterampilan berpikir kritis kelas eksperimen lebih besar dibandingkan kelas kontrol.

Setelah diketahui bahwa peningkatan keterampilan berpikir kritis siswa pada kedua kelas berada pada kategori sedang, maka untuk mengetahui efek treatment terhadap keterampilan berpikir kritis siswa digunakan Cohen's d effect size. Besarnya dampak strategi writing to learn terhadap peningkatan keterampilan berpikir kritis disajikan pada TABEL 4 berikut.

TABEL 4. Keefektifan Strategi Writing to Learn Terhadap Keterampilan Berpikir Kritis

\begin{tabular}{|c|c|c|c|c|c|c|}
\hline \multirow{2}{*}{ Kelas } & \multicolumn{2}{|c|}{ Rata-Rata } & \multicolumn{2}{|c|}{ STDev } & \multirow{2}{*}{ Sd $_{\text {pooled }}$} & \multirow{2}{*}{$d$} \\
\hline & Pretest & Posttest & Pretest & Posttest & & \\
\hline Eksperimen & 1,96 & 67,91 & 6,80 & 7,83 & \multirow{2}{*}{11,81} & \multirow{2}{*}{1,1} \\
\hline Kontrol & 9,33 & 54,67 & 14,57 & 14,62 & & \\
\hline
\end{tabular}

Berdasarkan TABEL 4, effect Size untuk keterampilan berpikir kritis yang diperoleh yaitu sebesar 1,1 , dan termasuk ke dalam kriteria tinggi. Jadi dapat dikatakan bahwa strategi writing to learn efektif untuk meningkatkan keterampilan berpikir kritis siswa.

Secara statistik kemampuan kognitif dan keterampilan berpikir kritis awal siwa kelas kontrol lebih baik daripada kelas eksperimen, namun, peningkatan kemampuan kognitif dan keterampilan berpikir kritis kelas eksperimen lebih baik dibandingkan kelas kontrol. Hal ini terjadi karena strategi writing to learn baik untuk memperkuat potensi siswa, salah satunya dapat membangun pengetahuan siswa. Sebagaimana Waters, P. M (2014) telah mengemukakan bahwa writing to learn adalah suatu strategi yang sangat berpengaruh dalam memperkuat potensi siswa dalam setiap disiplin dan di semua tingkatan dari SD hingga perguruan tinggi. Selain itu, Galbraith (dalam Chen, Y. C et al, 2013) menjelaskan bahwa menulis dapat dipandang sebagai epistimologis, yaitu dapat

dilihat sebagai proses yang mengarah pada pembangunan pengetahuan.

Proses menulis di sini membantu siswa membangun dan memodifikasi pemahamannya. Terlebih lagi pada setiap tahapan menulis jurnal, siswa dilatihkan kognitif dan berpikir kritisnya. Menurut Fellows (dalam Atasoy, S., 2013), siswa yang menulis untuk menghubungkan konsep-konsep akan 
memiliki pemahaman yang lebih baik daripada siswa yang tidak. Swafford dan Bryan (dalam Atasoy, S., 2013) mangungkapkan bahwa strategi writing to learn membantu siswa dalam hal metakognitifnya ketika membangun atau memodifikasi pemahaman konsep.

Tugas menulis dalam pembelajaran writing to learn dapat membantu siswa untuk mengulangi dan memperkuat pemahamannya, serta dapat membantu dalam perkembangan berpikir kritis, analisis, dan aplikasi, sehingga siswa menjadi pemikir yang lebih baik. Santa, C. M. dan Havens, L. T (1991) mengungkapkan bahwa menulis dapat mengembangkan keterampilan mengamati dan berpikir secara ilmiah dan tidak hanya membantu siswa dalam mengorganisasi pemikirannya, akan tetapi menulis juga memungkinkan siswa untuk berperan aktif dalam proses pembelajaran.

\section{Hubungan antara Kualitas Menulis dengan Peningkatan Kemampuan Kognitif dan Keterampilan Berpikir Kritis Siswa}

Tugas menulis yang telah dikerjakan siswa pada kelas eksperimen diolah dengan rubrik yang diadopsi dari Sinaga, P (2014). Berikut nilai tugas menulis siswa kelas eksperimen ditunjukkan pada TABEL 5.

TABEL 5. Nilai Tugas Menulis Siswa Kelas Eksperimen

\begin{tabular}{|c|c|c|c|}
\hline \multicolumn{3}{|c|}{ Rata - Rata Nilai } & \multirow{2}{*}{$\begin{array}{c}\text { Rata - Rata Nilai } \\
\text { Tugas Menulis }\end{array}$} \\
\hline Tugas Menulis 1 & Tugas Menulis 2 & Tugas Menulis 3 & \\
\hline 57,82 & 51,91 & 49,07 & 52,93 \\
\hline
\end{tabular}

Hubungan antara kualitas menulis dengan peningkatan kemampuan kognitif siswa dapat dihitung dengan menggunakan korelasi linear. Berdasarkan hasil perhitungan yang telah dilakukan, diperoleh $F_{\text {te }}=1,54$ dan $F_{0,95(15 / 8)}=3,22$ dengan taraf signifikansi $\alpha=0,05$. Karena $F_{\text {te }}(1,54)<F_{0,95(15 / 8)}=3,22$, maka dapat disimpulkan bahwa persamaan regresi tersebut linier, dengan kata lain kualitas menulis dan peningkatan kemampuan kognitif saling memperngaruhi secara linear. Adapun koefisien korelasinya yaitu $r=0,63$ dan termasuk dalam kategori tingkat hubungan tinggi.

Sedangkan hubungan antara kualitas menulis dengan peningkatan keterampilan berpikir kritis siswa dihitung pula dengan menggunakan korelasi linear. Berdasarkan hasil perhitungan yang telah dilakukan, diperoleh $F_{\text {te }}=2,93$ dan $F_{0,95(15 / 8)}=3,22$ dengan taraf signifikansi $\alpha=0,05$. Karena $F_{\text {te }}(2,93)<F_{0,95(15 / 8)}=3,22$, maka dapat disimpulkan bahwa persamaan regresi tersebut linier, dengan kata lain kualitas menulis dan peningkatan keterampilan berpikir kritis saling memperngaruhi secara linear. Adapun koefisien korelasinya yaitu $r=0,24$ dan termasuk dalam kategori tingkat hubungan rendah.

Hasil yang diperoleh menunjukkan bahwa kemampuan kognitif dan keterampilan berpikir kritis siswa meningkat ketika kualitas hasil menulis siswa tinggi. Ketika siswa menulis, siswa menuangkan pemahamannya. Semakin baik kualitas tulisan, maka siswa tersebut dianggap telah memahami materi tersebut secara jelas, luas, dan mendalam. Sebagaimana pernyataan dari Ruiz-Primo et al (dalam Chen, Y. C et al, 2013) bahwa: "engaging students in the construction of explanations is likely to have a positive impact in students' learning and achievement of the content".

Selanjutnya, dalam menulis jurnal, siswa mengalami pengulangan bacaan. Untuk memulai menulis, siswa membaca berbagai sumber mengenai materi yang akan ditulis, sehingga siswa membaca materi tersebut secara berulang. Melibatkan siswa dalam pengulangan bacaan memiliki dampak positif pada siswa, yaitu siswa dilatihkan kemampuan kognitif dan keterampilan berpikir kritisnya, salah satu contohnya yaitu siswa memahami dan menyimpulkan hasil dari membacanya. Peha, S. (2003de) mengungkapkan mengenai pentingnya menulis, yaitu salah satunya adalah hasil tulisan merupakan cara yang bagus untuk menilai pengetahuan siswa. Pada dasarnya, siswa tidak dapat menulis dengan jelas mengenai suatu topik apabila mereka tidak memahaminya. Penelitian yang telah dilakukan oleh Hand (dalam Abell, S. K., 2006) menyebutkan bahwa siswa yang menulis untuk menjelaskan pembelajaran sains mereka lebih baik pemahaman sainsnya daripada siswa yang menulis hanya untuk meringkas. Hal ini menjadikan adanya korelasi antara kualitas menulis dengan peningkatan kemampuan kognitif dan keterampilan berpikir siswa. 


\section{PENUTUP}

Berdasarkan hasil analisis data penelitian yang telah dipaparkan sebelumnya, maka dapat disimpulkan beberapa hal, yaitu sebagai berikut:

1. Peningkatan kemampuan kognitif dan keterampilan berpikir kritis $\langle g\rangle$ siswa kelas eksperimen yang belajar menggunakan strategi writing to learn lebih tinggi dibandingkan dengan siswa kelas kontrol, namun bila diinterpretasikan menurut kriteria Hake, keduanya termasuk pada kriteria sedang

2. Strategi writing to learn memberikan dampak terhadap peningkatan kemampuan kognitif dan keterampilan berpikir kritis siswa dengan kriteria tinggi dibandingkan dengan siswa yang pembelajarannya menggunakan strategi lain

3. Peningkatan kemampuan kognitif siswa dipengaruhi oleh kualitas menulisnya dengan kriteria tinggi dan peningkatan keterampilan berpikir kritis juga dipengaruhi oleh kualitas menulisnya dengan kriteria rendah.

\section{UCAPAN TERIMAKASIH}

Terimakasih kepada Bapak/Ibu KBK Writing in Science \& Teaching Material Development di prodi Pendidikan Fisika FPMIPA UPI yang telah memberikan masukan-masukan yang berharga.

\section{REFERENSI}

Abell, S. K 2006, 'On Writing in Science'. NSTA: Science and Children, pp. 60-61

Atasoy, S 2013, 'Effect of Writing-to-learn Strategy on Undergraduates' Conceptual Understanding of Electrostatics', Asia-Pacific Edu Res, vol. 22, no. 4, pp. 593-602.

Chen, Y. C, Hand, B, \& McDowell, L 2013, 'The Effects of Writing-to-Learn Activities on Elementary Students' Conceptual Understanding: Learning About Force and Motion Through Writing to Older Peers', Wiley Periodicals, Inc.Sci Ed, vol. 97, no. 5, pp. 745-771.

Departemen Pendidikan Nasional 2006, Standar Isi Kurikulum Tingkat Satuan Pendidikan Sekolah Menengah Atas, Jakarta, Depdiknas.

Departemen Pendidikan dan Kebuayaan 2013, Standar Isi Kurikulum 2013, Jakarta, Depdikbud.

Ennis, R. H 1985, 'A Logical Basis for Measuring Critical Thinking Skills', Association for Supervision and Curriculum Development, pp. 45-48.

Fellow, N. J 1994. 'A Window intp thinking using students writing to understand conceptual change in science learning', Journal of science teaching, vol. 31, pp. 985-1001.

Lai, E. R 2011, 'Critical Thinking: A Literature Review [Laporan penelitian]', Pearson's Research Reports, pp. 2.

Michigan Science Teacher Association 1987, Writing Across the Curriculum, Ann Arbor, Michigan, pp. 4.

Peha, S 2003, Writing Across the Curriculum, Teaching That Makes Sense, Inc.

Santa, C. M \& Havens, L. T 1991, 'Teaching and Learning Science Through Writing', Science learning: Processes and applications, Newark, DE, International Reading Association, pp. 2-9.

Sinaga, P 2014, Pengembangan Program Perkuliahan Fisika Sekolah untuk Meningkatkan Kompetensi Menulis Materi Ajar Calon Guru Menggunakan Multi Modus Representasi [Disertasi], Universitas Pendidikan Indonesia, Sekolah Pasca Sarjana.

Sinaga, P, Suhandi, A \& Liliasari 2013, 'Improving the ability to write teaching materials among student of preservice physics teacher program through learning to write activity using multymodal 
representation', Proceeding International seminar on Mathematics Science and Computer Science education, vol. 1, pp 80-86.

Susana, E. S. H, \& Sriyansah 2015, 'Analisis Didaktis Berdasarkan Kemampuan Kognitif dan Keterampilan Berpikir Kritis Siswa pada Materi Kalor', JPPPF - Jurnal Penelitian \& Pengembangan Pendidikan Fisika, vol. 1, no. 2, pp. 39-43.

Sugiyono 2014, Metode Penelitian Pendidikan (Pendekatan Kuantitatif, Kualitatif, dan R\&D), Bandung, Alfabeta.

Waters, P. M 2014, 'Writing to learn', Oman, German University of Technology in Oman Halban, pp. 6-10. 